\title{
Exposure as Collected Location
}

National Cancer Institute

\section{Source}

National Cancer Institute. Exposure as Collected Location. NCI Thesaurus. Code

C117488.

The site in or on the body at which the exposure as collected test or result is performed or collected. 